Article

\title{
Antagonistic Strain Bacillus amyloliquefaciens XZ34-1 for Controlling Bipolaris sorokiniana and Promoting Growth in Wheat
}

\author{
Yanjie Yi ${ }^{1,2, *(D)}$, Youtian Shan ${ }^{1,2}$, Shifei Liu ${ }^{1}$, Yanhui Yang ${ }^{1,2}$, Yang Liu ${ }^{1,2}$, Yanan Yin ${ }^{1,2}$, Zhipeng Hou ${ }^{1,2}$, \\ Pengyu Luan ${ }^{1,2}$ and Ruifang Li ${ }^{1,2, *}$
}

1 School of Biological Engineering, Henan University of Technology, Zhengzhou 450001, China; shanyoutian@stu.haut.edu.cn (Y.S.); 201720040312@stu.haut.edu.cn (S.L.); yyhui2004@haut.edu.cn (Y.Y.); liuyang01@stu.haut.edu.cn (Y.L.); christa@stu.haut.edu.cn (Y.Y.); 2021920170@stu.haut.edu.cn (Z.H.); 2021920159@stu.haut.edu.cn (P.L.)

2 The Key Laboratory of Functional Molecules for Biomedical Research, Zhengzhou 450001, China

* Correspondence: yiyanjie@haut.edu.cn (Y.Y.); lrf@haut.edu.cn (R.L.); Tel.: +86-371-67756513 (Y.Y. \& R.L.)

check for

updates

Citation: Yi, Y.; Shan, Y.; Liu, S.; Yang, Y.; Liu, Y.; Yin, Y.; Hou, Z.; Luan, P.; Li, R. Antagonistic Strain Bacillus amyloliquefaciens XZ34-1 for Controlling Bipolaris sorokiniana and Promoting Growth in Wheat. Pathogens 2021, 10, 1526. https:// doi.org/10.3390/pathogens10111526

Academic Editors: Huijun Wu and Xuewen Gao

Received: 10 October 2021

Accepted: 19 November 2021

Published: 22 November 2021

Publisher's Note: MDPI stays neutral with regard to jurisdictional claims in published maps and institutional affiliations.

Copyright: (c) 2021 by the authors. Licensee MDPI, Basel, Switzerland. This article is an open access article distributed under the terms and conditions of the Creative Commons Attribution (CC BY) license (https:/ / creativecommons.org/licenses/by/ $4.0 /)$.
Abstract: Common root rot, caused by Bipolaris sorokiniana, is one of the most prevalent diseases of wheat and has led to major declines in wheat yield and quality worldwide. Here, strain XZ34-1 was isolated from soil and identified as Bacillus amyloliquefaciens based on the morphological, physiological, biochemical characteristics and $16 \mathrm{~S}$ rDNA sequence. Culture filtrate (CF) of strain XZ34-1 showed a high inhibition rate against $B$. sorokiniana and had a broad antifungal spectrum. It also remarkably inhibited the mycelial growth and spore germination of B. sorokiniana. In pot control experiments, the incidence and disease index of common root rot in wheat seedlings were decreased after treatment with $C$, and the biological control efficacy was significant, up to $78.24 \%$. Further studies showed XZ34-1 could produce antifungal bioactive substances and had the potential of promoting plant growth. Lipopeptide genes detection with PCR indicated that strain XZ34-1 may produce lipopeptides. Furthermore, activities of defense-related enzymes were enhanced in wheat seedlings after inoculation with $B$. sorokiniana and treatment with $C F$, which showed induced resistance could be produced in wheat to resist pathogens. These results reveal that strain XZ34-1 is a promising candidate for application as a biological control agent against B. sorokiniana.

Keywords: Bacillus amyloliquefaciens; Bipolaris sorokiniana; common root rot; biological control; growth promoting

\section{Introduction}

Common root rot is one of the most prevalent diseases of wheat and has become a severe threat to global wheat production [1]. It is characterized by the development of necrotic lesions on the roots and sub-crown. The lesions are dark brown to black in color. The development of symptoms on the roots is usually followed by symptoms on the crowns of wheat [2-4]. Common root rot has been reported in many wheat-growing regions, such as China, North America, the Middle East, Australia, etc. [5-7]. As the pathogenic fungi of wheat common root rot, Bipolaris sorokiniana results from soil-borne or seed-borne inoculum and can attack all wheat parts, including seeds, roots, shoots, and leaves, and results in yield losses in wheat [2]. When severely infected, it can also cause the aboveground parts of the wheat to die. In addition, it seriously affects the quality and nutrition of wheat flour [8].

Cultural management, resistant varieties and fungicides are the most practices to control common root rot of wheat. Cultural management is important for controlling plant diseases. The rotation of wheat with cruciferous crops and soil solarization were found to reduce the incidence of common root rot $[9,10]$. Zero tillage with rotation and residue retention reduced the incidence of root rot of wheat in Mexico, but they are difficult to implement in China due to the large population and limited arable land [11]. 
Fewer completely resistant wheat varieties have been reported in traditional breeding [2] Although chemical fungicides have become an important strategy for common root rot control, they create imbalances in the microbial community, which may have adverse effects on beneficial microorganisms and lead to the development of resistant pathogens [12,13].

Exploiting biocontrol agents has acquired intense attention nowadays. It is important to find antagonistic strains that can complement cultural and chemical practices in the field [2]. In recent years, biological control has been used in the control of common root rot of wheat. Some antagonistic strains (e.g., Pseudomonas mediterranea, Pseudomomas fluorescens, Nocardiopsis dassonvillei, Lysobacter enzymogenes and Chaetomium globosum, et al.) were found to inhibit B. sorokiniana [14-17]. Among the antagonistic bacteria, Bacillus spp. are widely present in soil and are considered to have the highest biocontrol potential, being of greater interest than other species, and their long-term viability is more conducive to the development of commercial products. Many studies have reported that using Bacillus strains as biological control agents are an effective and safe control strategy [16-18]. Bacillus spp. can form endospores to resist hostile conditions, thus giving Bacillus-based products an advantage over other biocontrol microorganisms [18]. Up to now, more than 100 commercial products of Bacillus preparations have been registered in China [19]. Among the Bacillus species, B. amyloliquefaciens are known for their ability to promote plant growth and fight a wide range of plant-associated diseases, and they are considered promising biocontrol agents [18,19]. Many studies have reported that B. amyloliquefaciens could control diseases caused by a variety of pathogens [20-23]. For example, B. amyloliquefaciens S76-3 produces three classes of cyclic lipopeptides, including Iturin, Plipastatin and Surfactin, which exhibit strong antifungal activity against the toxigenic Fusarium graminearum [22]. Furthermore, B. amyloliquefaciens has shown the ability to promote plant growth [24,25]. The potential contribution to plant growth promotion by B. amyloliquefaciens UCMB5113 is its ability to produce IAA, acetoin and siderophore [26].

To obtain more effective strains and further investigate their actions for exploiting microbial agents to control wheat root rot, in the present work, strain XZ34-1 antagonistic to $B$. sorokiniana was isolated and identified, and its biological control effect, antifungal mechanism and plant growth-promoting characteristics were evaluated.

\section{Results}

\subsection{Screening of Antagonistic Bacteria}

A total of 81 bacteria were isolated from the soil of the Tibetan plateau. All of them were tested for inhibition on pathogenic fungi B. sorokiniana by the plate confrontation method, and the five most effective antagonistic isolates were selected. The Oxford cup method was used to test the antagonistic effect of five isolates against the pathogenic fungi, and the results showed that XZ34-1 had the strongest antifungal effect and was selected for further studies. The inhibition rates of XZ34-1 culture filtrate (CF) on Bipolaris sorokiniana, Fusarium graminearum, Rhizoctonia zeae, Aspergillus niger and Aspergillus flavus were 53.52, 43.06, 46.70, 35.77 and 34.35\%, respectively (Table 1).

Table 1. Inhibition rates of mycelia growth of five aseptic filtrate against pathogens.

\begin{tabular}{cccccc}
\hline & \multicolumn{5}{c}{ Inhibition Rate (\%) } \\
\cline { 2 - 6 } Strain & $\begin{array}{c}\text { Bipolaris } \\
\text { sorokiniana }\end{array}$ & $\begin{array}{c}\text { Fusarium } \\
\text { graminearum }\end{array}$ & $\begin{array}{c}\text { Rhizoctonia } \\
\text { zeae }\end{array}$ & $\begin{array}{c}\text { Aspergillus } \\
\text { niger }\end{array}$ & $\begin{array}{c}\text { Aspergillus } \\
\text { flavus }\end{array}$ \\
\hline XZ34-1 & $53.52 \pm 0.86 \mathrm{a}$ & $43.06 \pm 1.73 \mathrm{a}$ & $46.70 \pm 1.37 \mathrm{a}$ & $35.77 \pm 1.22 \mathrm{a}$ & $34.35 \pm 1.49 \mathrm{a}$ \\
XZ33-1 & $32.66 \pm 1.77 \mathrm{~b}$ & $30.41 \pm 0.75 \mathrm{~b}$ & $33.93 \pm 0.59 \mathrm{~b}$ & $19.98 \pm 2.84 \mathrm{~b}$ & $26.94 \pm 1.42 \mathrm{~b}$ \\
XZ22-1 & $22.02 \pm 2.25 \mathrm{c}$ & $12.41 \pm 1.77 \mathrm{~d}$ & $26.70 \pm 2.58 \mathrm{c}$ & - & - \\
XZ19-2 & $15.86 \pm 3.04 \mathrm{~d}$ & $19.94 \pm 1.17 \mathrm{c}$ & $26.25 \pm 1.69 \mathrm{c}$ & $9.22 \pm 1.62 \mathrm{c}$ & $8.73 \pm 1.73 \mathrm{c}$ \\
XZ11-2 & $15.17 \pm 2.29 \mathrm{~d}$ & $13.59 \pm 2.42 \mathrm{~d}$ & $12.64 \pm 1.87 \mathrm{~d}$ & - & -
\end{tabular}

Values represent the means \pm standard of at least nine replicates. Different letters indicate significant differences using Duncan's multiple range test $(p \leq 0.05)$. 


\subsection{Identification of Antagonistic Strain XZ34-1}

Strain XZ34-1 is Gram-positive and forms endospores. Pure colonies of XZ34-1 after $48 \mathrm{~h}$ incubation showed creamy white in appearance without pigmentation, rough surface, rounded overall, smooth margins and opaque. The bacteria produce acids, not gases, from glucose decomposition. The V-P test, the tests of inorganic and organic phosphorus dissolving, siderophore production, nitrogen fixation, protease and pectinase production are all positive (Table 2). It indicated that the isolate XZ34-1 belonged to Bacillus spp. Based on the $16 \mathrm{~S}$ rDNA sequence alignments, a phylogenetic tree was constructed (Figure 1). The strain XZ34-1 showed the highest homology (98.25\%) with B. amyloliquefaciens F321 (MG836692), and the strains were clustered on the same evolutionary branch as B. amyloliquefaciens. According to morphological, physical and chemical characteristics and molecular analysis, the strains XZ34-1 were identified as B. amyloliquefaciens.

Table 2. Morphological and biochemical characteristics of XZ34-1.

\begin{tabular}{ccc}
\hline \multicolumn{2}{c}{ Morphological and Biochemical Characteristics } & XZ34-1 \\
\hline Cell morphology & Gram's reaction & Gram positive \\
\hline \multirow{2}{*}{ Colony morphology } & Endospores & + \\
& Morphology & Rounded \\
& Pigment & Creamy white \\
& Surface & Rough \\
Biochemical tests & Margin & Smooth \\
& Opacity & Opaque \\
& Nitrate reduction & - \\
& Citrate utilization & - \\
& V-P test & - \\
\hline${ }^{\prime \prime}$ positive; ${ }^{\prime \prime}$ " negative. & Methyl Red & Acids, not gas
\end{tabular}

\subsection{Inhibitory Effect of the Antagonistic Strain XZ34-1 CF on B. sorokiniana}

Inhibitory rates of the antagonistic strain XZ34-1 CF on B. sorokiniana were detected by evaluating mycelial dry weight and spore germination. The results showed the CF of strain XZ34-1 could remarkably inhibit the mycelial growth and spore germination of B. sorokiniana and indicated that active metabolites might be present in the CF of strain XZ34-1 (Figure 2).

\subsection{Biocontrol Efficacy of XZ34-1 CF on Common Root Rot Caused by B. sorokiniana}

The biocontrol efficacy of strain XZ34-1 against $B$. sorokiniana was evaluated using wheat seedlings in pots. Figure $3 \mathrm{~A} 1, \mathrm{~A} 2$ showed that wheat seedlings wilted, and the roots developed necrotic lesions (dark brown) after being infected with B. sorokiniana. Wheat seedlings returned to normal after treatment with 50\% carbendazim and XZ34-1 CF (Figure 3B1,B2,C1,C2). Compared with the positive control (50\% carbendazim) and the negative control (sterile water), CF of XZ34-1 exhibited significant biological control efficacy $78.24 \%$ on the incidence of common root rot in wheat seedlings; however, this was lower than carbendazim (Table 3). These results indicated XZ34-1 CF has great application value. 


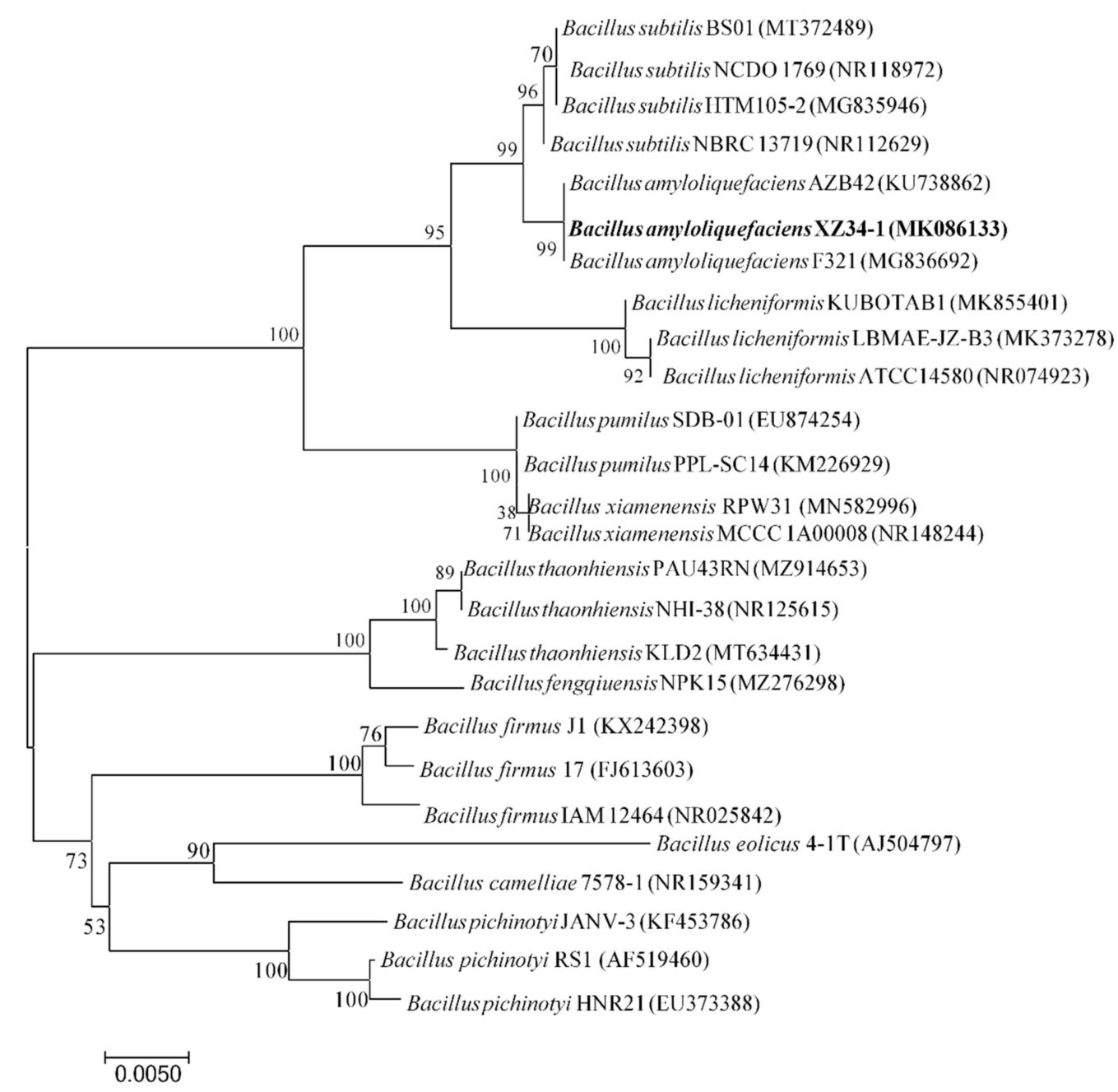

Figure 1. Phylogenetic tree constructed based on 16S rDNA sequences. The analysis was performed using the NeighborJoining method of MEGA 7.0 (1000 bootstrap values).

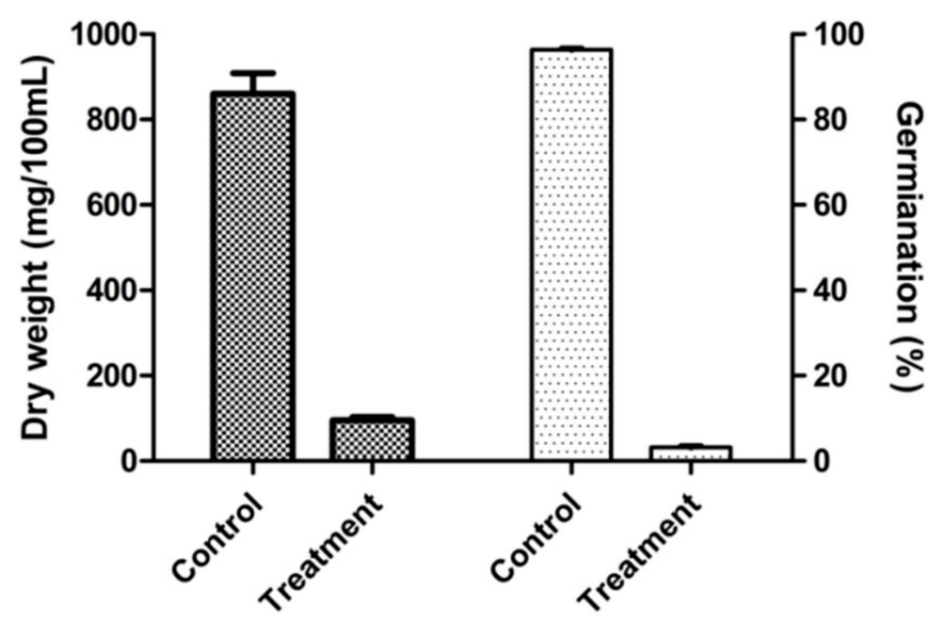

Figure 2. Inhibition effect of XZ34-1 CF on B. sorokiniana. Error bar represents the standard error of the means of replicates $(n=10)$. 

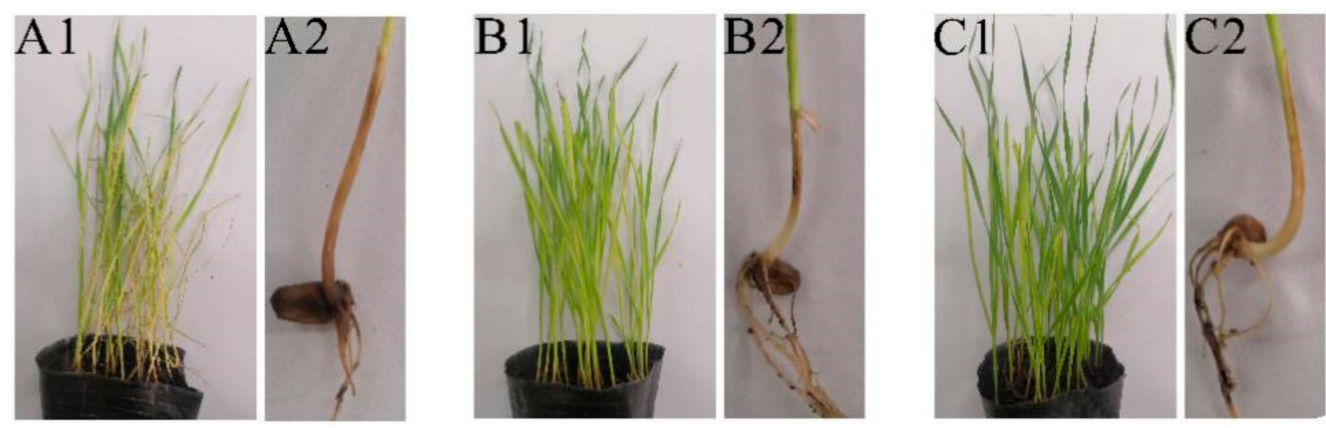

Figure 3. Biocontrol efficiency of XZ34-1 CF on common root rot caused by B. sorokiniana. The pathogen $B$. sorokiniana was pre-inoculated on all of the wheat seedlings tested. (A1,A2) were sterile water treatment (control); (B1,B2) were 50\% carbendazim treatment; (C1,C2) were XZ34-1 CF treatment.

Table 3. Biocontrol efficacy of XZ34-1 CF on common root rot.

\begin{tabular}{cccc}
\hline Treatments & $\begin{array}{c}\text { Disease Incidence } \\
\text { Rate (\%) }\end{array}$ & Disease Index & $\begin{array}{c}\text { Control } \\
\text { Efficacy (\%) }\end{array}$ \\
\hline $\begin{array}{c}\text { Sterile water control } \\
\text { Carbendazim }\end{array}$ & $98.05 \pm 2.76 \mathrm{a}$ & $65.73 \pm 11.29 \mathrm{a}$ & - \\
treatment & $41.24 \pm 10.87 \mathrm{c}$ & $9.16 \pm 2.20 \mathrm{~b}$ & $85.67 \pm 4.67$ \\
CF treatment & $54.13 \pm 9.16 \mathrm{~b}$ & $14.17 \pm 3.01 \mathrm{~b}$ & $78.24 \pm 4.66$ \\
\hline
\end{tabular}

The data presented are the mean values of five independent experiments. Standard errors of the mean values are presented after the \pm symbol. Letters in the same column indicate DMRT at $p<0.05$.

\subsection{Potential of Strain XZ34-1 in Fungal Antagonism and Growth Promotion}

The potential of strain XZ34-1 for antagonizing fungi and promoting plant growth was evaluated by characterizing several indicators on a plate. The results showed that XZ34-1 had the potential to decompose organic phosphorus and inorganic phosphorus and to fix nitrogen. However, the nitrogen-fixation ability of the strain XZ34-1 should be confirmed by PCR amplification of nifH gene encoding for nitrogenase activity. In addition, it could secrete protease, pectinase and siderophore. However, it could not produce cellulase and chitinase. For IAA (Indole acetic acid) detection, the pink color did not appear, indicated that IAA was not produced by strain XZ34-1.

\subsection{Detection of Lipopeptide Biosynthesis Genes of Strain 34-1}

Strain XZ34-1 contains genes involved in lipopeptide biosynthesis, which can be detected by PCR method with primer pairs designed to detect genes involved in Bacyllomicin (BMYBa, BMYBb), Bacilysin (BACa, BACb), Bacillaene (BAE), Iturin (ITU), Fengycin (fenD) and Surfactin (srfAA, srfP) biosynthesis. As shown in Table 4, amplified fragments of the expected size of Bacyllomicin, Bacilysin, Bacillaene and Iturin were obtained. Therefore, lipopeptides may be produced by antagonistic strain XZ34-1 and are the active substances partially responsible for the antifungal activity.

\subsection{Effect of XZ34-1 CF on Cell Membrane Integrity in B. sorokiniana}

After staining by propidium iodide (PI), the mycelia of B. sorokiniana with and without CF treatment were observed using a laser scanning confocal microscope (LSCM). The surface of mycelia treated by CF became rough, and the tip was swollen. In addition, PI staining showed that obvious red fluorescence was present in the mycelia treated by $\mathrm{CF}$, while it was absent in the control mycelia (Figure 4). These results indicated that the membrane integrity of mycelia was destroyed by CF of antagonistic strain XZ34-1. 
Table 4. Genetic markers used for detection of lipopeptide biosynthesis genes of XZ34-1.

\begin{tabular}{|c|c|c|c|c|c|}
\hline Product & Genes & Primers & Primer Sequence $\left(5^{\prime}-3^{\prime}\right)$ & $\begin{array}{l}\text { Expected/Detected } \\
\text { Size (bp) }\end{array}$ & References \\
\hline \multirow[t]{2}{*}{ Bacyllomicin } & BMYBa & $\begin{array}{l}\text { BMYBa-R } \\
\text { BMYBa-R }\end{array}$ & $\begin{array}{l}\text { CGAAACGACGGTATGAAT } \\
\text { TCTGCCGTTCCTTATCTC }\end{array}$ & $371 /$ yes & Farzand, A. et al. [27] \\
\hline & $\mathrm{BMYBb}$ & $\begin{array}{l}\text { BMYBb-F } \\
\text { BMYBb-R }\end{array}$ & $\begin{array}{l}\text { GAATCCCGTTGTTCTCCAAA } \\
\text { GCGGGTATTGAATGCTTGTT }\end{array}$ & $370 /$ yes & Zhang, L. et al. [28] \\
\hline \multirow[t]{2}{*}{ Bacilysin } & $\mathrm{BACa}$ & $\begin{array}{l}\text { BACa-F } \\
\text { BACa-R }\end{array}$ & $\begin{array}{l}\text { ATCTTTATGGCGGCAGTC } \\
\text { ATACGGCTTACAGGCGAG }\end{array}$ & 595/yes & Farzand, A. et al. [27] \\
\hline & $\mathrm{BACb}$ & $\begin{array}{l}\mathrm{BACb}-\mathrm{F} \\
\mathrm{BACb}-\mathrm{R}\end{array}$ & $\begin{array}{l}\text { CAGCTCATGGGAATGCTTTT } \\
\text { CTCGGTCCTGAAGGGACAAG }\end{array}$ & 498/yes & Mora, I. et al. [29] \\
\hline Bacillaene & BAE & $\begin{array}{l}\text { BAE-F } \\
\text { BAE-R }\end{array}$ & $\begin{array}{l}\text { ATGTCAGCTCAGTTTCCGCA } \\
\text { GATCGCCGTCTTCAATTGCC }\end{array}$ & 688/yes & Compaore, C. S. et al. [30] \\
\hline Iturin & ITU & $\begin{array}{l}\text { ITU-F } \\
\text { ITU-R }\end{array}$ & $\begin{array}{l}\text { GGCTGCTGCAGATGCTTTAT } \\
\text { TCGCAGATAATCGCAGTGAG }\end{array}$ & 423/yes & Mora, I. et al. [29] \\
\hline Fengycin & fenD & $\begin{array}{l}\text { FEND-F } \\
\text { FEND-R }\end{array}$ & $\begin{array}{l}\text { TTTGGCAGCAGGAGAAGTTT } \\
\text { GCTGTCCGTTCTGCTTTTTC }\end{array}$ & $964 /$ no & Athukorala, S. N. P. et al. [31] \\
\hline \multirow[t]{2}{*}{ Surfactin } & srfAA & $\begin{array}{l}\text { srfAA-F } \\
\text { srfAA-R }\end{array}$ & $\begin{array}{l}\text { TCGGGACAGGAAGACATCAT } \\
\text { CCACTCAAACGGATAATCCTG }\end{array}$ & $201 /$ no & Khedher, S.B. et al. [32] \\
\hline & sfP & $\begin{array}{l}\text { SFP-F } \\
\text { SFP-R }\end{array}$ & $\begin{array}{l}\text { ATGAAGATTTACGGAATTTA } \\
\text { TTATAAAAGCTCTTCGTACG }\end{array}$ & $675 /$ no & Chung, S. et al. [33] \\
\hline
\end{tabular}

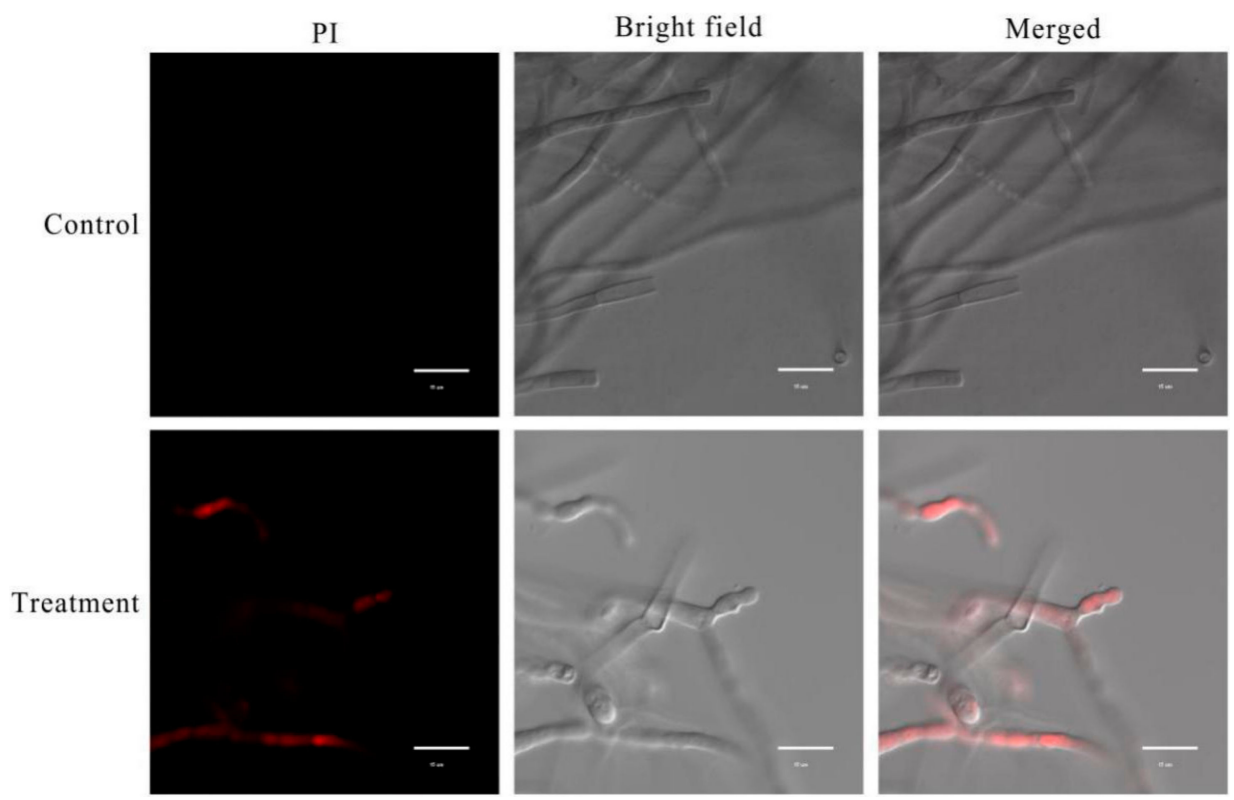

Figure 4. Effects of XZ34-1 CF on the morphology and cell membrane integrity of B. sorokiniana. Scale bar, $15 \mu \mathrm{m}$.

\subsection{Effects of XZ34-1 CF on Antioxidant Activity of Wheat Seedlings}

Activities of superoxide dismutase (SOD), peroxidase (POD), phenylalanine ammonia lyase (PAL) and malondialdehyde (MDA) concentrations in the root tissue extracts of wheat were detected after inoculating B. sorokiniana and treatments with XZ34-1 CF and $50 \%$ carbendazim. Figure $5 \mathrm{~A}-\mathrm{C}$ showed that the antioxidant enzyme activities in both the XZ34-1 CF-treated group (T4) and the 50\% carbendazim-treated group (T3) were higher and even surpassed those of normal-grown wheat seedlings (T1) compared to the inoculation with B. sorokiniana only (T2). The SOD, POD and PAL activities in the T4 group were significantly increased by 2.0, 9.1 and 4.5 -fold, respectively, compared to the T2 group. MDA is one of the most important products of membrane lipid peroxidation. Therefore, the degree of membrane lipid peroxidation can be reflected by MDA content and can indirectly reflect the damage degree of the membrane system. Figure 5D revealed that the content of MDA in the T4 group was significantly lower than that in the T2 group, only $67.2 \%$ of its concentration. 
A

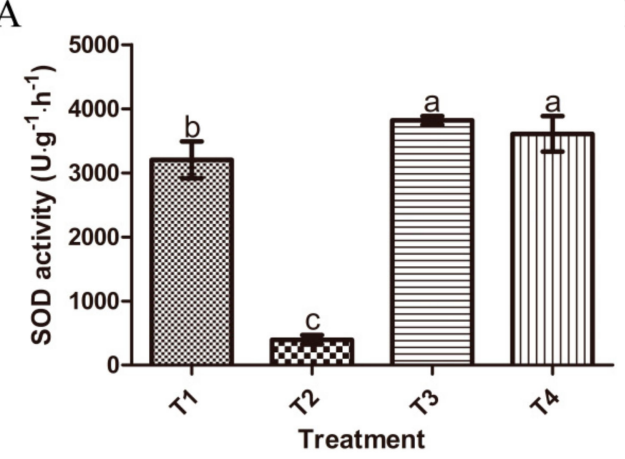

C

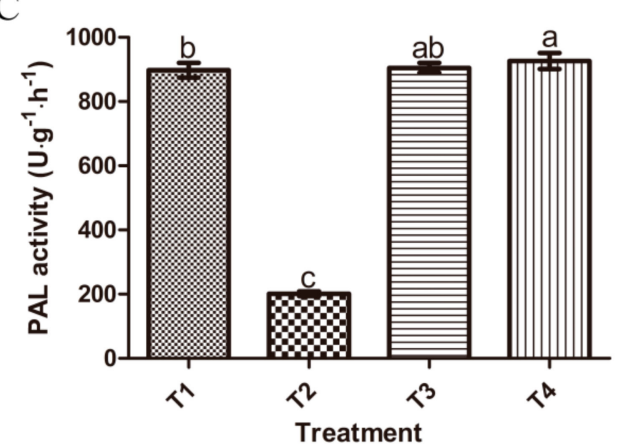

B

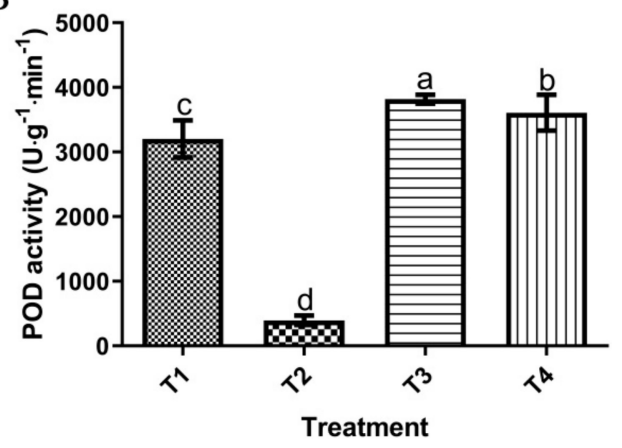

$\mathrm{D}$

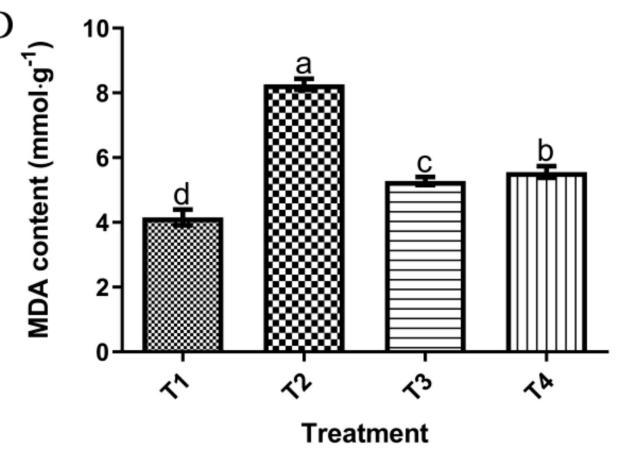

Figure 5. Superoxide dismutase (SOD), peroxidase (POD) and phenylalanine ammonia lyase (PAL) activities and malondialdehyde (MDA) content in wheat seedlings. T1 (control, normal-grown wheat seedlings), T2 (inoculation with B. sorokiniana), T3 (carbendazim treatment after inoculation with B. sorokiniana) and T4 (XZ34-1 CF treatment after inoculation with B. sorokiniana). $(\mathrm{A})=\mathrm{SOD}$ activity, (B) $=$ POD activity,$(\mathbf{C})=$ PAL activity,$(\mathbf{D})=$ MDA content. The data presented are the mean value of at least five repeats. Letters on bars indicate DMRT at $p<0.05$.

\section{Discussion}

Common root rot reduces wheat yield and causes huge economic losses. B. sorokiniana is soil-borne or seed-borne, and once conditions are favorable, it develops rapidly and infects plants. Eber Villa-Rodríguez et al. reported that Bacillus subtilis TE3 could inhibit B. sorokiniana mycelia dry weight through culture filtrate [34]. Filtrate of liquid culture of Chaetomium spp. strain 22-10 also inhibited the mycelial growth of $B$. sorokiniana, indicating that strain 22-10 produced secondary metabolites against $B$. sorokiniana [16]. In the current study, 81 strains of bacteria were isolated from soil, and five of them exhibited strong antagonistic potential against B. sorokiniana. Strain XZ34-1 was identified as B. amyloliquefaciens and showed a high inhibition rate against pathogenic $B$. sorokiniana. We investigated the antifungal activities of CF of XZ34- 1 against $B$. sorokiniana and found that the CF can inhibit mycelial dry weight and conidial germination. The pot control experiments showed that CF of B. amyloliquefaciens XZ34-1 had a significant influence on common root rot of wheat caused by $B$. sorokiniana, indicating the higher potential of XZ34-1 as a biological agent to control B. sorokiniana in wheat.

The antifungal mechanisms by Bacillus to control plant diseases and induce plant growth differ due to differences in bacterial species. Therefore, understanding the biocontrol mechanism of B. amyloliquefaciens XZ34-1 will help us to evaluate and improve the biocontrol effect of $B$. sorokiniana in wheat crops. The current work indicates that B. amyloliquefaciens XZ34-1 exhibits plant growth-promoting traits. Strain XZ34-1 was able to grow in a nitrogen-free medium and indicated its potential to fix atmospheric $\mathrm{N}_{2}$. Zakry, F. A. et al. reported that Bacillus sphaericus strain UPMB-10 has the nifH gene and produces nitrogenase (EC 1.18.6.1), which can fix atmospheric $\mathrm{N}_{2}$ and provide it to plants to enhance plant growth and yield [35]. Strain XZ34-1 was also able to solubilize organic and inorganic phosphorus, which is an important feature of enhancing soil fertility and plant growth. The study by Muhammad Tahir et al. showed that the combined ap- 
plication of bio-organic phosphate and phosphorus-solubilizing bacteria MWT 14 could harvest better wheat yield with low fertilizer inputs under an arid climate [36]. The ability of siderophore production in strain XZ34-1 was confirmed by a CAS-blue agar assay. Similarly, Saoussen Ben Khedher et al. revealed that B. subtilis V26 was able to produce siderophore [32]. Siderophores have an exceptionally high affinity for $\mathrm{Fe}^{3+}$ and are able to bind the Fe-siderophore complexes, thus promoting Fe uptake by microorganisms, while the complexes can also be used by plants to increase iron content inside plant tissues and improve plant growth [37]. Nocardiopsis dassonvillei as a biocontrol agent can control wheat common root rot and enhance the growth of wheat attributed to the ability to produce siderophores, hydrogen cyanide and IAA, which are commonly known features for the plant-growth promotion and biocontrol activities of a given strain [15].

The control of plant pathogens by Bacillus is closely related to its ability to secrete hydrolytic enzymes. Antimicrobial activity through the production of fungal cell wall degrading enzymes is probably an important mechanism used by biocontrol bacteria to inhibit pathogens. Lopes et al. reported that six S. cerevisiae isolates could inhibit pathogen germination, produce killer activity and hydrolytic enzymes when in contact with the fungus wall [38]. The current study demonstrated the ability of strain XZ34-1 to produce protease and pectinase; however, no cellulase or chitinase production was detected. It indicated the protease and pectinase might limit the pathogen invasion into host wheat tissues. Several reports showed that such enzymes seem to be stable enough for semifield or field applications, as their range of activity appears adequate to inhibit fungal phytopathogens growing in acidic and mesophilic environments [39,40].

Another important mechanism by Bacillus for suppressing plant pathogens is the production of antifungal metabolites and antibiotics [41-45]. The biocontrol fungus Chaetomium globosum is effective in inhibiting B. sorokiniana associated with wheat common root rot owing to the production of secondary metabolites by C. globosum [16]. Six genes involved in lipopeptide biosynthesis were detected by PCR in strain XZ34-1. The results indicated XZ34-1 could produce Bacyllomicin, Bacilysin, Bacillaene and Iturin. These antifungal metabolites have well-recognized potential uses in biocontrol [32]. Bacillus velezensis AK-0 was shown to co-produce the lipopeptides iturin and bacilysin, which have potent antifungal effects against bitter rot in apples [46]. Bacillomycin L and Fengycin A compounds were isolated from strain G341, which controlled the development of rice blast, sheath blight, tomato gray mold and red pepper anthracnose [47]. Lipopeptides from Bacillus megaterium strain WL-3 containing three subfamilies, surfactant, Iturin A and Fengycin A, which control late blight and promote potato plant growth [43]. In our opinion, it is necessary to assay and evaluate the lipopeptide of XZ34-1 in the future to further explore its mechanism of action and broaden its application.

Maintaining the stability of defense systems in the host plant is a promising mechanism for effective biological control of fungal pathogens [48]. This study showed that CFtreated wheat seedlings were observed increasing on SOD, POD and PAL activities and MDA content compared to normally grown wheat. It indicated the degree of damage to the membrane system was significantly lower than that of wheat inoculated with B. sorokiniana only. Several reports have shown that the strains can directly trigger plant defense mechanisms by themselves and induce the plant's self-defense systems in response to an external attack by fungal pathogens $[16,35,36]$. In our results, the SOD, POD and CAT activities were significantly enhanced, and the MDA content was significantly reduced in the treated diseased seedlings. As shown in Figure 3, the treated wheat has returned to normal growth. Moreover, CF-treated and carbendazim-treated wheat seedlings were observed increasing obviously on SOD, POD and PAL activities compared to normalgrown seedlings. Since CF treatment and carbendazim treatment caused oxidative stress in the seedlings and in order to scavenge harmful reactive oxygen species, the enzymatic antioxidative defense system of wheat becomes activated. This resulted in enhanced activities of antioxidative enzymes. The internal defense system of plants helps to protect them from oxidative stress caused by stressful conditions [48-51]. Based on these data, 
we speculate the CF of XZ34-1 controls the common root rot caused by B. sorokiniana by producing some antibiotic substances to prevent pathogen infection, altering plant physiological and metabolic responses, stabilizing plant cell membranes and rejuvenating plants after pathogen infection. In the future, field applications should be conducted to investigate the biocontrol effects of XZ34-1 CF against common root rot of wheat to support the development of commercial formulation.

\section{Materials and Methods}

\subsection{Materials}

Soil samples used for isolating the antagonistic bacteria were provided by Dr. Yu Shi of the Institute of Soil Science, Chinese Academy of Sciences. Pathogenic fungi B. sorokiniana, Fusarium graminearum, Rhizoctonia zeae, Aspergillus niger and Aspergillus flavus) were kept at $-80 \pm 2{ }^{\circ} \mathrm{C}$ in $15 \%$ glycerol stocks in the School of Biological Engineering, Henan University of Technology. The chemical fungicide carbendazim was purchased from the local market. Wheat varieties used in pot control were Qiule 2122 (purchased from Henan Qiule Seeds Technology, Co., Ltd., Zhengzhou, China). The medium was LB medium (5 g yeast extract, $10 \mathrm{~g}$ peptone, $10 \mathrm{~g} \mathrm{NaCl}, 15-20 \mathrm{~g}$ agar, $1000 \mathrm{~mL}$ distilled water, $\mathrm{pH}$ 7) and potato dextrose agar (PDA) medium (20 g glucose, 200 g potato, agar 15-20 g agar, $1000 \mathrm{~mL}$ distilled water, $\mathrm{pH} 7$ ).

\subsection{Isolation and Screening of Antagonistic Bacteria}

Soil samples were collected from different locations on the Tibetan Plateau. Soil samples were transported to the laboratory until strains of bacteria were isolated using the serial dilution method $[19,52,53]$. The strains with better antagonistic effects were selected and the Oxford cup method was used to determine their inhibition activities [54]. Briefly, the antagonistic bacteria were adjusted to a concentration of $10^{8} \mathrm{cfu} \mathrm{mL}^{-1}$ and inoculated into conical flasks $(250 \mathrm{~mL})$ containing $100 \mathrm{~mL} \mathrm{LB}$ liquid medium at $1 \%$ inoculum, which was cultured at $37^{\circ} \mathrm{C}$ with shaking at $180 \mathrm{r} \mathrm{min}^{-1}$ for $72 \mathrm{~h}$. The fermentation broth was centrifuged at $8000 \mathrm{r} \mathrm{min}^{-1}$ for $15 \mathrm{~min}$ and filtered through a $0.22 \mu \mathrm{m}$ pore size membrane filter to obtain a culture filtrate (CF). Disks containing pathogenic fungi were placed in the center of the PDA plate, then an Oxford cup was placed $30 \mathrm{~mm}$ from the center, and $200 \mu \mathrm{L}$ of CF was transferred into the cup. The PDA plate without CF was set as a control group, and the same pathogenic fungi were cultured for the same period of time. Nine replicate plates were maintained for each $\mathrm{CF}$. The inhibitory rate was calculated following the formula: inhibitory rate $(\%)=(C-T) / C \times 100 \%$, where $C$ is the diameter of the control fungus and $\mathrm{T}$ is the diameter of the treatment fungus. The strain showing the strongest antifungal effect was coded as XZ34-1 and preserved in $40 \%$ glycerol on the slope of the test tube at $-80^{\circ} \mathrm{C}$ for further processing [19].

\subsection{Identification of Strain XZ34-1}

\subsubsection{Morphological, Physiological and Biochemical Tests}

Antagonistic strain XZ34-1 was cultured on LB medium plate and placed at $28^{\circ} \mathrm{C}$ for $24 \mathrm{~h}$ to observe colony characteristics, such as color, morphology and growth properties. Physiological and biochemical tests were performed using universal methods [55], including gram staining, nitrate reduction, citrate utilization, Voges-Proskauer (V-P) reaction, methyl red and glucose decomposition test.

\subsubsection{Molecular Identification of Antagonistic Strain XZ34-1}

Genomic DNA of XZ34-1 was extracted using the phenol-chloroform method [35]. The 16S rDNA gene was amplified using the bacterial universal primer pair 16SF (5'-AGA GTT TGA TCA TGG CTC AG-3') and 16SR (5'-ACG GTT ACC TTG TTA CGA CTT-3') primers $[34,56]$. PCR was performed using a Taq DNA polymerase kit (Sangon Biotech Co., Ltd., Shanghai, China) in $25 \mu \mathrm{L}$ reactions. The PCR conditions were as follows: $94{ }^{\circ} \mathrm{C}$ for $5 \mathrm{~min}$, followed by 32 cycles of $30 \mathrm{~s}$ at $94^{\circ} \mathrm{C}, 30 \mathrm{~s}$ at $55^{\circ} \mathrm{C}$ and $90 \mathrm{~s}$ at $72{ }^{\circ} \mathrm{C}$, then a final 
extension step of $10 \mathrm{~min}$ at $72{ }^{\circ} \mathrm{C}$. Then the PCR product was sent to Sangon Biotech Co., Ltd. (Shanghai, China) for sequencing. The $16 \mathrm{~S}$ rDNA sequence of XZ34-1 was submitted to GenBank (NCBI, USA; http:/ / www.Ncbi.nlm.nih.gov) under the accession number MK086133. The DNA sequences were blasted in the GenBank, and the phylogenetic tree was constructed with MEGA 7.0 software using the Maximum Likelihood method with 1000 bootstrap replications [57].

\subsection{Inhibitory Effect of the Antagonistic Strain XZ34-1 CF on B. sorokiniana}

Spore suspension $\left(1 \times 10^{6} \mathrm{cfu} / \mathrm{mL}\right)$ of $B$. sorokiniana was inoculated in a conical flask $(250 \mathrm{~mL}$ ) containing $97 \mathrm{~mL}$ PDB at an inoculation volume of $2 \%$, then $1 \mathrm{~mL}$ of fermentation filtrate was added into and incubated with $180 \mathrm{r} / \mathrm{min}$ under $28^{\circ} \mathrm{C}$ for $7 \mathrm{~d}$. Sterile distilled water was used as a control. The fermentation broth was subsequently centrifuged in a $50 \mathrm{~mL}$ centrifuge tube at $5000 \mathrm{r} / \mathrm{min}$ for $15 \mathrm{~min}$. The precipitated mycelia from each flask were collected and washed 3 times with sterile distilled water, then dried till the weight was constant at $60^{\circ} \mathrm{C}$ and weighed. The spore germination rate was measured after incubation of B. sorokiniana in spore solution for $2 \mathrm{~h}$.

\subsection{Pot Control Tests}

To evaluate the control efficacy of XZ34-1 on common root rot, pot experiments were carried out under greenhouse conditions. Qiule 2122, one of the most widely planted cultivars in Henan Province, China, was used. Before sowing, wheat seeds were surface disinfected with $0.5 \% \mathrm{NaClO}$ and then washed with sterile distilled water. The seeds were sown on plastic pots (30 cm in diameter) filled with horticulture soil. Pot experiments were conducted in a greenhouse from 25 to $30^{\circ} \mathrm{C}$ and relative humidity ranging from 30 to $70 \%$. After 14 days, $10 \mathrm{~mL}$ of $B$. sorokiniana spore suspension $\left(1 \times 10^{6} \mathrm{cfu} / \mathrm{mL}\right)$ was poured around the roots of wheat in the pot. The roots of each pot of wheat were irrigated with $20 \mathrm{~mL}$ of $\mathrm{CF}$ after being inoculated with B. sorokiniana. Carbendazim ( $50 \%$ wettable powder) was used as a positive control, and water was used as the negative control. Each group of treatments had five replicates with at least 25 wheat plants in each replicate. Disease severity was evaluated on the 10th day after inoculation, and the scoring standard was 0 to 4 . Level 0 indicates healthy plants, level 1 indicates incidence $\leq 25 \%$, level 2 indicates incidence $>25$ to $50 \%$, level 3 indicates incidence $>50$ to $75 \%$, level 4 indicates incidence $>75 \%$. The disease incidence rate (DIR), disease index (DI), and control efficacy (CE) were using the following formulas [58].

$$
\begin{gathered}
\operatorname{DIR}(\%)=(\mathrm{n} / \mathrm{N}) \times 100 \\
\mathrm{DI}=\sum[(\mathrm{Ni} \times \mathrm{i}) /(\mathrm{N} \times 4)] \times 100 \\
\mathrm{CE}(\%)=[(\mathrm{DIck}-\mathrm{DIt}) / \mathrm{DIck}] \times 100
\end{gathered}
$$

where $\mathrm{n}$ is the number of infected plants, $\mathrm{N}$ is the total number of investigated plants, $\mathrm{Ni}$ denotes the number of infected plants of a certain severity, i denotes a certain severity, 4 denotes the highest severity, DIck indicates the disease index of the control group, and DIt indicates the disease index of the treatment group.

\subsection{Detection of Antifungal and Plant Growth-Promoting Traits}

The plate test was used to detect antifungal and growth-promoting traits of strain XZ34-1. Indole acetic acid (IAA) production, Nitrogen-fixation production, phosphate solubilization, siderophore production, hydrolases, including cellulase, chitinase, protease and pectinase, were detected by the methods described by Ben Khedher et al. [32].

\subsection{PCR Detection of Lipopeptide Biosynthesis Genes}

Structural genes DNA of Bacyllomicin, Bacilysin, Bacillaene, Iturin, Fengycin and Surfactin in the antagonistic strain XZ34-1 was detected by PCR. Primers used to amplify the genes encoding for lipopeptides were summarized in Table 2. The PCR conditions were 
as follows: $94{ }^{\circ} \mathrm{C}$ for $5 \mathrm{~min}$, followed by 32 cycles of $30 \mathrm{~s}$ at $94{ }^{\circ} \mathrm{C}, 30 \mathrm{~s}$ at $54-61{ }^{\circ} \mathrm{C}$ and $90 \mathrm{~s}$ at $72{ }^{\circ} \mathrm{C}$, then a final elongation step of $10 \mathrm{~min}$ at $72{ }^{\circ} \mathrm{C}$. The amplification products were detected by agarose gel electrophoresis (1.2\% agarose, $120 \mathrm{~V}, 25 \mathrm{~min})$, stained with ethidium bromide and then visualized under UV light.

\subsection{Effect of CF on Cell Membrane Integrity in B. sorokiniana}

The effect of CF on cell membrane integrity was detected by propidium iodide (PI) staining [59]. B. sorokiniana $\left(1 \times 10^{6} \mathrm{cfu} / \mathrm{mL}\right)$ was inoculated into $40 \mathrm{~mL}$ of PDB and incubated at $28^{\circ} \mathrm{C}$ for $72 \mathrm{~h}$, and $10 \mathrm{~mL}$ of $\mathrm{CF}$ was added and incubated for another $12 \mathrm{~h}$. LB liquid medium without CF was set as a control. Mycelia were collected by centrifugation at $8000 \mathrm{rpm} / \mathrm{min}$ for $10 \mathrm{~min}$ and washed twice with phosphate buffer (PBS), then resuspended in PBS and stained with PI $(10 \mu \mathrm{g} / \mathrm{mL})$ for $10 \mathrm{~min}$ in the dark. After staining, the mycelia with uniform thickness and even surfaces were washed twice and observed using a laser scanning confocal microscope (LSCM).

\subsection{Detection of Antioxidant Activity of Wheat Root}

Antioxidant Enzyme activities of SOD, peroxidase POD, PAL and MDA concentrations in the root tissue extracts of wheat subjected to different treatments were detected. Root extracts were prepared according to the method of Vaishnav et al. and Zhang W with minor modification [60]. Root tissues were ground in a mortar and pestle containing liquid nitrogen. The prepared powder was immersed in ice-cold $50 \mathrm{mM}$ potassium phosphate buffer ( $\mathrm{pH} 7.8$ ) containing 1\% polyvinylpyrrolidone (PVP) and $1 \mathrm{mM}$ ethylene diamine tetra-acetate (EDTA). The homogenates were centrifuged at $8000 \mathrm{rpm}$ at $4{ }^{\circ} \mathrm{C}$ for $20 \mathrm{~min}$. The supernatants were immediately used to determine SOD, POD and PAL enzyme activities and MDA concentrations. In the case of every enzyme under detection, each treatment consisted of at least five replicates.

\subsubsection{SOD Activity}

The activity of SOD was assessed by nitroblue tetrazolium (NBT) photoreduction according to the method of He S. Z. et al. with minor modifications [61]. The reaction mixture $(3.0 \mathrm{~mL})$ containing phosphate buffer $(25 \mathrm{mM}, \mathrm{pH} 7.8)$, L-methionine (13 $\mathrm{mM})$, riboflavin $\left(2.0 \times 10^{-3} \mathrm{mM}\right)$, NBT $\left(7.5 \times 10^{-2} \mathrm{mM}\right)$, EDTA $\left(1.0 \times 10^{-2} \mathrm{mM}\right)$ and $0.1 \mathrm{~mL}$ of enzyme extracts were incubated at $30^{\circ} \mathrm{C}$ for $25 \mathrm{~min}$ under cool-white fluorescent light at 4000 lx. The complete reaction medium incubated in the dark without the enzyme was used as the dark control. Samples were placed in the dark after the reaction had stopped, and then the optical density was measured at $560 \mathrm{~nm}$.

\subsubsection{POD Activity}

The activity of POD was measured by the modified method of Choudhary [62]. The reaction mixture was prepared by adding $6.9 \mathrm{~mL}$ of distilled water, $1.0 \mathrm{~mL}$ of $0.1 \%$ guaiacol and $1.0 \mathrm{~mL}$ of $0.18 \%$ hydrogen peroxide (the reference was replaced with $1.0 \mathrm{~mL}$ of distilled water) into $1.0 \mathrm{~mL}$ of the enzyme extract. The reaction was carried out at $30^{\circ} \mathrm{C}$ for $10 \mathrm{~min}$ then terminated through the addition of $0.2 \mathrm{~mL}$ of $5.0 \%$ metaphosphoric acid, and the absorbance was measured at $470 \mathrm{~nm}$.

\subsubsection{PAL Activity}

The activity of PAL was measured by the modified method of Shekhar Jain et al. [63]. Conversion of L-phenylalanine to cinnamic acid was performed at $30{ }^{\circ} \mathrm{C}$. The reaction mixture was prepared by adding $2.0 \mathrm{~mL}$ of $100 \mathrm{mM}$ Tris- $\mathrm{HCl}$ buffer $(\mathrm{pH} 8.8)$ and $1.0 \mathrm{~mL}$ of $20 \mathrm{mM}$ phenylalanine into $1.0 \mathrm{~mL}$ of the enzyme extract. The reference used $1.0 \mathrm{~mL}$ of extraction buffer instead of the sample. The reaction was terminated through the addition of $0.2 \mathrm{~mL}$ of $6 \mathrm{M} \mathrm{HCl} 60 \mathrm{~min}$ after the start of the reaction, and the absorbance was measured at $290 \mathrm{~nm}$. 


\subsubsection{MDA Concentration}

The MDA concentration was determined by the method described by Anket Sharma et al. with slight modifications [50]. The reaction mixture consisted of $1.5 \mathrm{~mL}$ of $0.1 \%$ thiobarbituric acid (TBA) and $1.5 \mathrm{~mL}$ of root extract, which was reacted in a boiling water bath for $15 \mathrm{~min}$ and then rapidly cooled down and centrifuged at $9000 \mathrm{rpm}$ for $5 \mathrm{~min}$ at $4{ }^{\circ} \mathrm{C}$. The absorbance at $450 \mathrm{~nm}, 532 \mathrm{~nm}$ and $600 \mathrm{~nm}$ was determined using the supernatant.

\subsection{Statistical Analysis}

Each experiment was carried out at least three times. All data were expressed as mean \pm SD and analyzed by one-way analysis of variance at the $5 \%$ level. Statistical differences between treatments were analyzed by Duncan's multiple range test at a 5\% significance level.

\section{Conclusions}

B. amyloliquefaciens XZ34-1 showed a high inhibition rate against pathogenic B. sorokiniana and had a broad antifungal spectrum. CF of XZ34-1 exhibited significant control effects on common root rot. Further analysis showed that B. amyloliquefaciens XZ34-1 had plant growth-promoting characteristics and could produce lipopeptides. Furthermore, activities of defense-related antioxidant enzymes in wheat seedlings were enhanced after inoculating with B. sorokiniana and treating with CF. Therefore, CF of XZ34-1 is a potential candidate for application as a biological control agent against B. sorokiniana.

Author Contributions: Y.Y. (Yanjie Yi), Y.S. and S.L. designed the research; Y.S., S.L., Y.L. and Y.Y. (Yanan Yin) performed the experiments; Y.Y. (Yanjie Yi) and Y.S. wrote the manuscript; Y.S., S.L., Z.H. and P.L. made the data analysis. Y.Y. (Yanhui Yang) and R.L. revised the manuscript. All authors have read and agreed to the published version of the manuscript.

Funding: This work was supported by the National Natural Science Foundation of China (81973417); the Innovative Funds Plan of Henan University of Technology (2020ZKCJ23); and the Program for the Innovative Research Team (in Science and Technology) in the University of Henan Province (19IRTSTHN008).

Institutional Review Board Statement: Not applicable.

Informed Consent Statement: Not applicable.

Data Availability Statement: Not applicable.

Conflicts of Interest: The authors declare no conflict of interest.

\section{References}

1. Su, J.; Zhao, J.; Zhao, S.; Li, M.; Pang, S.; Chen, S.; Chen, F.; Zhen, W.; Kang, Z.; Wang, X. Genetics of Resistance to Common Root Rot (Spot Blotch), Fusarium Crown Rot, and Sharp Eyespot in Wheat. Front. Genet. 2021, 12, 699342. [CrossRef]

2. Al-Sadi, A.M. Bipolaris sorokiniana-Induced Black Point, Common Root Rot, and Spot Blotch Diseases of Wheat: A Review. Front. Cell. Infect. Microbiol. 2021, 11, 9. [CrossRef]

3. Al-Sadi, A.M.; Deadman, M.L. Influence of Seed-borne Cochliobolus sativus (Anamorph Bipolaris sorokiniana) on Crown Rot and Root Rot of Barley and Wheat. J. Phytopathol. 2010, 158, 683-690. [CrossRef]

4. Qostal, S.; Kribel, S.; Chliyeh, M.; Serghat, S.; Karimaselmaoui, A.O.; Touhami, A.O.; Zaarati, H.; Benkirane, R.; Allal Douira, A. Study of the fungal complex responsible for root rot of wheat and barley in the north-west of Morocco. Plant Arch. 2019, 19, 2143-2157.

5. Fernandez, M.R.; Ulrich, D.; Brandt, S.A.; Zentner, R.P.; Wang, H.; Thomas, A.G.; Olfert, O. Crop Management Effects on Root and Crown Rot of Wheat in West-Central Saskatchewan, Canada. Agron. J. 2011, 103, 756-765. [CrossRef]

6. Poole, G.J.; Harries, M.; Huberli, D.; Miyan, S.; MacLeod, W.J.; Lawes, R.; McKay, A. Predicting Cereal Root Disease in Western Australia Using Soil DNA and Environmental Parameters. Phytopathology 2015, 105, 1069-1079. [CrossRef] [PubMed]

7. Xu, F.; Yang, G.Q.; Wang, J.M.; Song, Y.L.; Liu, L.L.; Zhao, K.; Li, Y.H.; Han, Z.H. Spatial Distribution of Root and Crown Rot Fungi Associated with Winter Wheat in the North China Plain and Its Relationship with Climate Variables. Front. Microbiol. 2018, 9, 14. [CrossRef] [PubMed]

8. Kang, X.X.; Zhang, W.L.; Cai, X.C.; Zhu, T.; Xue, Y.R.; Liu, C.H. Bacillus velezensis CC09: A Potential 'Vaccine' for Controlling Wheat Diseases. Mol. Plant Microbe Interact. 2018, 31, 623-632. [CrossRef] 
9. Campanella, V.; Mandala, C.; Angileri, V.; Miceli, C. Management of common root rot and Fusarium foot rot of wheat using Brassica carinata break crop green manure. Crop Prot. 2020, 130, 7. [CrossRef]

10. Saremi, H.; Saremi, H. Isolation of the most common Fusarium species and the effect of soil solarisation on main pathogenic species in different climatic zones of Iran. Eur. J. Plant Pathol. 2013, 137, 585-596. [CrossRef]

11. Govaerts, B.; Mezzalama, M.; Sayre, K.; Crossa, J.; Lichter, K.; Troch, V.; Vanherck, K.; De Corte, P.; Deckers, J. Long-term consequences of tillage, residue management, and crop rotation on selected soil micro-flora groups in the subtropical highlands. Appl. Soil Ecol. 2008, 38, 197-210. [CrossRef]

12. Shanmugam, V.; Kanoujia, N. Biological management of vascular wilt of tomato caused by Fusarium oxysporum $f$. sp lycospersici by plant growth-promoting rhizobacterial mixture. Biol. Control 2011, 57, 85-93. [CrossRef]

13. Pereg, L.; McMillan, M. Scoping the potential uses of beneficial microorganisms for increasing productivity in cotton cropping systems. Soil Biol. Biochem. 2015, 80, 349-358. [CrossRef]

14. Ullah, H.; Yasmin, H.; Mumtaz, S.; Jabeen, Z.; Naz, R.; Nosheen, A.; Hassan, M.N. Multitrait Pseudomonas spp. Isolated from Monocropped Wheat (Triticum aestivum) Suppress Fusarium Root and Crown Rot. Phythopathology 2020, 110, 582-592. [CrossRef]

15. Allali, K.; Goudjal, Y.; Zamoum, M.; Bouznada, K.; Sabaou, N.; Zitouni, A. Nocardiopsis dassonvillei strain MB22 from the Algerian Sahara promotes wheat seedlings growth and potentially controls the common root rot pathogen Bipolaris sorokiniana. J. Plant Pathol. 2019, 101, 1115-1125. [CrossRef]

16. Yue, H.M.; Wang, M.; Gong, W.F.; Zhang, L.Q. The screening and identification of the biological control fungi Chaetomium spp. against wheat common root rot. FEMS Microbiol. Lett. 2018, 365, 6. [CrossRef] [PubMed]

17. Ozlem, K.; Gary, Y.Y. Comparison of strains of Lysobacter enzymogenes and PGPR for induction of resistance against Bipolaris sorokiniana in tall fescue. Biol. Control 2004, 30, 446-455. [CrossRef]

18. Miljaković, D.; Marinković, J.; Balešević-Tubić, S. The Significance of Bacillus spp. in Disease Suppression and Growth Promotion of Field and Vegetable Crops. Microorganisms 2020, 8, 1037. [CrossRef]

19. Cheng, X.K.; Ji, X.X.; Ge, Y.Z.; Li, J.J.; Qi, W.Z.; Qiao, K. Characterization of Antagonistic Bacillus methylotrophicus Isolated from Rhizosphere and Its Biocontrol Effects on Maize Stalk Rot. Phythopathology 2019, 109, 571-581. [CrossRef] [PubMed]

20. Shokry, M.E.; Ibrahim, S.D.; Wassief, A.Y. Biological control of pathogens associated with kernel black point disease of wheat. Crop Prot. 2017, 91, 13-19. [CrossRef]

21. Wang, B.; Yuan, J.; Zhang, J.; Shen, Z.; Zhang, M.; Li, R.; Ruan, Y.; Shen, Q. Effects of novel bioorganic fertilizer produced by Bacillus amyloliquefaciens W19 on antagonism of Fusarium wilt of banana. Biol. Fert. Soils 2013, 49, 435-446. [CrossRef]

22. Gong, A.D.; Li, H.P.; Yuan, Q.S.; Song, X.S.; Yao, W.; He, W.J.; Zhang, J.B.; Liao, Y.C. Antagonistic mechanism of iturin A and plipastatin A from Bacillus amyloliquefaciens S76-3 from wheat spikes against Fusarium graminearum. PLoS ONE 2015, 10, e0116871. [CrossRef] [PubMed]

23. Chen, X.; Zhang, Y.; Fu, X.; Li, Y.; Wang, Q. Isolation and characterization of Bacillus amyloliquefaciens PG12 for the biological control of apple ring rot. Postharvest Biol. Technol. 2016, 115, 113-121. [CrossRef]

24. Yu, Y.Y.; Xu, J.D.; Huang, T.X.; Zhong, J.; Yu, H.; Qiu, J.P.; Guo, J.H. Combination of beneficial bacteria improves blueberry production and soil quality. Food Sci. Nutr. 2020, 8, 5776-5784. [CrossRef]

25. Abadi, V.; Sepehri, M.; Rahmani, H.A.; Dolatabad, H.K.; Shamshiripour, M.; Khatabi, B. Diversity and abundance of culturable nitrogen-fixing bacteria in the phyllosphere of maize. J. Appl. Microbiol. 2021, 131, 898-912. [CrossRef] [PubMed]

26. Niazi, A.; Manzoor, S.; Asari, S.; Bejai, S.; Meijer, J.; Bongcam, R.E. Genome analysis of Bacillus amyloliquefaciens Subspp. plantarum UCMB5113: A rhizobacterium that improves plant growth and stress management. PLoS ONE 2014, 9, e104651. [CrossRef]

27. Farzand, A.; Moosa, A.; Zubair, M.; Khan, A.R.; Hanif, A.; Tahir, H.A.S.; Gao, X.W. Marker assisted detection and LC-MS analysis of antimicrobial compounds in different Bacillus strains and their antifungal effect on Sclerotinia sclerotiorum. Biol. Control 2019, 133, 91-102. [CrossRef]

28. Zhang, L.; Khabbaz, S.E.; Wang, A.; Li, H.; Abbasi, P.A. Detection and characterization of broad-spectrum antipathogen activity of novel rhizobacterial isolates and suppression of Fusarium crown and root rot disease of tomato. J. Appl. Microbiol. 2015, 118, 685-703. [CrossRef] [PubMed]

29. Mora, I.; Cabrefiga, J.; Montesinos, E. Antimicrobial peptide genes in Bacillus strains from plant environments. Int. Microbiol. 2011, 14, 213-223. [CrossRef] [PubMed]

30. Compaore, C.S.; Nielsen, D.S.; Ouoba, L.I.I.; Berner, T.S.; Nielsen, K.F.; Sawadogo-Lingani, H.; Diawara, B.; Ouedraogo, G.A.; Jakobsen, M.; Thorsen, L. Co-production of surfactin and a novel bacteriocin by Bacillus subtilis subsp subtilis H4 isolated from Bikalga, an African alkaline Hibiscus sabdariffa seed fermented condiment. Int. J. Food Microbiol. 2013, 162, 297-307. [CrossRef]

31. Athukorala, S.N.P.; Fernando, W.G.D.; Rashid, K.Y. Identification of antifungal antibiotics of Bacillus species isolated from different microhabitats using polymerase chain reaction and MALDI-TOF mass spectrometry. Can. J. Microbiol. 2009, 55, $1021-1032$. [CrossRef] [PubMed]

32. Khedher, S.B.; Mejdoub-Trabelsi, B.; Tounsi, S. Biological potential of Bacillus subtilis V26 for the control of Fusarium wilt and tuber dry rot on potato caused by Fusarium species and the promotion of plant growth. Biol. Control 2021, 152, 10. [CrossRef]

33. Chung, S.; Kong, H.; Buyer, J.S.; Lakshman, D.K.; Lydon, J.; Kim, S.D.; Roberts, D.P. Isolation and partial characterization of Bacillus subtilis ME488 for suppression of soilborne pathogens of cucumber and pepper. Appl. Microbiol. Biotechnol. 2008, 80, 115-123. [CrossRef] [PubMed] 
34. Villa-Rodriguez, E.; Parra-Cota, F.; Castro-Longoria, E.; Lopez-Cervantes, J.; Santos-Villalobos, S.D. Bacillus subtilis TE3: A promising biological control agent against Bipolaris sorokiniana, the causal agent of spot blotch in wheat (Triticum turgidum L. subspp. durum). Biol. Control 2019, 132, 135-143. [CrossRef]

35. Zakry, F.A.A.; Shamsuddin, Z.H.; Rahim, K.A.; Zakaria, Z.Z.; Rahim, A.A. Inoculation of Bacillus sphaericus UPMB-10 to Young Oil Palm and Measurement of Its Uptake of Fixed Nitrogen Using the N-15 Isotope Dilution Technique. Microbes Environ. 2012, 27, 257-262. [CrossRef]

36. Tahir, M.; Khalid, U.; Ijaz, M.; Shah, G.M.; Naeem, M.A.; Shahid, M.; Mahmood, K.; Ahmad, N.; Kareem, F. Combined application of bio-organic phosphate and phosphorus solubilizing bacteria (Bacillus strain MWT 14) improve the performance of bread wheat with low fertilizer input under an arid climate. Braz. J. Microbiol. 2018, 49, 15-24. [CrossRef]

37. Glick, B.R. Plant growth-promoting bacteria: Mechanisms and applications. Scientifica 2012, 2012, 963401. [CrossRef]

38. Lopes, M.R.; Klein, M.N.; Ferraz, L.P.; da Silva, A.C.; Kupper, K.C. Saccharomyces cerevisiae: A novel and efficient biological control agent for Colletotrichum acutatum during pre-harvest. Microbiol. Res. 2015, 175, 93-99. [CrossRef] [PubMed]

39. Berini, F.; Casartelli, M.; Montali, A.; Reguzzoni, M.; Tettamanti, G.; Marinelli, F. Metagenome-Sourced Microbial Chitinases as Potential Insecticide Proteins. Front. Microbiol. 2019, 10, 12. [CrossRef] [PubMed]

40. Hjort, K.; Presti, I.; Elvang, A.; Marinelli, F.; Sjoling, S. Bacterial chitinase with phytopathogen control capacity from suppressive soil revealed by functional metagenomics. Appl. Microbiol. Biotechnol. 2014, 98, 2819-2828. [CrossRef] [PubMed]

41. Romero, D.; Vicente, A.; Rakotoaly, R.H.; Dufour, S.E.; Veening, J.W.; Arrebola, E.; Cazorla, F.M.; Kuipers, O.P.; Paquot, M.; PérezGarcía, A. The iturin and fengycin families of lipopeptides are key factors in antagonism of Bacillus subtilis toward Podosphaera fusca. Mol. Plant Microbe Interact. 2007, 20, 430-440. [CrossRef] [PubMed]

42. Ongena, M.; Jourdan, E.; Adam, A.; Michel, P.; Alain, B.; Bernard, J.; Arpigny, J.L.; Philippe, T. Surfactin and fengycin lipopeptides of Bacillus subtilis as elicitors of induced systemic resistance in plants. Environ. Microbiol. 2007, 9, 1084-1090. [CrossRef]

43. Wang, Y.; Liang, J.; Zhang, C.; Wang, L.; Gao, W.; Jiang, J. Bacillus megaterium WL-3 Lipopeptides Collaborate against Phytophthora infestans to Control Potato Late Blight and Promote Potato Plant Growth. Front. Microbiol. 2020, 11, 1602. [CrossRef] [PubMed]

44. Wang, Y.; Zhang, C.; Liang, J.; Wu, L.; Gao, W.; Jiang, J. Iturin A Extracted from Bacillus subtilis WL-2 Affects Phytophthora infestans via Cell Structure Disruption, Oxidative Stress, and Energy Supply Dysfunction. Front. Microbiol. 2020, 11, 536083. [CrossRef] [PubMed]

45. Zhang, L.; Sun, C. Fengycins, cyclic lipopeptides from marine Bacillus subtilis strains, kill the plant-pathogenic fungus Magnaporthe grisea by inducing reactive oxygen species production and chromatin condensation. Appl. Environ. Microbiol. 2018, 84, e00445-e18. [CrossRef] [PubMed]

46. Kim, Y.S.; Lee, Y.; Cheon, W.; Park, J.; Kwon, H.T.; Balaraju, K.; Kim, J.; Yoon, Y.J.; Jeon, Y. Characterization of Bacillus velezensis AK-0 as a biocontrol agent against apple bitter rot caused by Colletotrichum gloeosporioides. Sci. Rep. 2021, 11, 14. [CrossRef] [PubMed]

47. Lim, S.M.; Yoon, M.Y.; Choi, G.J.; Choi, Y.H.; Jang, K.S.; Shin, T.S.; Park, H.W.; Yu, N.H.; Kim, Y.H.; Kim, J.C. Diffusible and Volatile Antifungal Compounds Produced by an Antagonistic Bacillus velezensis G341 against Various Phytopathogenic Fungi. Plant Pathol. J. 2017, 33, 488-498. [CrossRef]

48. Jamali, H.; Sharma, A.; Roohi; Srivastava, A.K. Biocontrol potential of Bacillus subtilis RH5 against sheath blight of rice caused by Rhizoctonia solani. J. Basic Microbiol. 2020, 60, 268-280. [CrossRef]

49. Van Wees, S.C.M.; Van der Ent, S.; Pieterse, C.M.J. Plant immune responses triggered by beneficial microbes. Curr. Opin. Plant Biol. 2008, 11, 443-448. [CrossRef]

50. Sharma, A.; Kumar, V.; Yuan, H.; Kanwar, M.K.; Bhardwaj, R.; Thukral, A.K.; Zheng, B. Jasmonic Acid Seed Treatment Stimulates Insecticide Detoxification in Brassica juncea L. Front. Plant Sci. 2018, 9, 1609. [CrossRef]

51. Fatma, F.; Verma, S.; Kamal, A.; Srivastava, A. Phytotoxicity of pesticides mancozeb and chlorpyrifos: Correlation with the antioxidative defence system in Allium cepa. Physiol. Mol. Biol. Plants 2018, 24, 115-123. [CrossRef] [PubMed]

52. Wang, X.Y.; Zhou, X.N.; Cai, Z.B.; Guo, L.; Chen, X.L.; Chen, X.; Liu, J.Y.; Feng, M.F.; Qiu, Y.W.; Zhang, Y.; et al. A Biocontrol Strain of Pseudomonas aeruginosa CQ-40 Promote Growth and Control Botrytis cinerea in Tomato. Pathogens 2021, 10, 17. [CrossRef] [PubMed]

53. Kumar, P.; Dubey, R.C.; Maheshwari, D.K. Bacillus strains isolated from rhizosphere showed plant growth promoting and antagonistic activity against phytopathogens. Microbiol. Res. 2012, 167, 493-499. [CrossRef]

54. Guo, D.S.; Yuan, C.H.; Luo, Y.Y.; Chen, Y.H.; Lu, M.H.; Chen, G.C.; Ren, G.W.; Cui, C.B.; Zhang, J.T.; An, D.R. Biocontrol of tobacco black shank disease (Phytophthora nicotianae) by Bacillus velezensis Ba168. Pestic. Biochem. Physiol. 2020, 165, 10. [CrossRef]

55. Guerrero, R. Bergey's manuals and the classification of prokaryotes. Int. Microbiol. 2001, 4, 103-109. [CrossRef]

56. Weisburg, W.G.; Barns, S.M.; Pelletier, D.A.; Lane, D.J. 16 S ribosomal DNA amplification for phylogenetic study. J. Bacteriol. 1991, 173, 697-703. [CrossRef] [PubMed]

57. Kumar, S.; Stecher, G.; Tamura, K. MEGA7: Molecular Evolutionary Genetics Analysis Version 7.0 for Bigger Datasets. Mol. Biol. Evol. 2016, 33, 1870-1874. [CrossRef] [PubMed]

58. Chen, L.; Wu, Y.D.; Chong, X.Y.; Xin, Q.H.; Wang, D.X.; Bian, K. Seed-borne endophytic Bacillus velezensis LHSB1 mediate the biocontrol of peanut stem rot caused by Sclerotium rolfsii. J. Appl. Microbiol. 2020, 128, 803-813. [CrossRef] [PubMed] 
59. Kim, K.; Lee, Y.; Ha, A.; Kim, J.I.; Park, A.R.; Yu, N.H.; Son, H.; Choi, G.J.; Park, H.W.; Lee, C.W.; et al. Chemosensitization of Fusarium graminearum to Chemical Fungicides Using Cyclic Lipopeptides Produced by Bacillus amyloliquefaciens Strain JCK-12. Front. Plant Sci. 2017, 8, 16. [CrossRef]

60. Vaishnav, A.; Jain, S.; Kasotia, A.; Kumari, S.; Gaur, R.K.; Choudhary, D.K. Effect of nitric oxide signaling in bacterial-treated soybean plant under salt stress. Arch. Microbiol. 2013, 195, 571-577. [CrossRef]

61. He, S.Z.; Han, Y.F.; Wang, Y.P.; Zhai, H.; Liu, Q.C. In vitro selection and identification of sweetpotato (Ipomoea batatas (L.) Lam.) plants tolerant to NaCl. Plant Cell Tissue Organ Cult. 2009, 96, 69-74. [CrossRef]

62. Choudhary, D.K. Plant growth-promotion (PGP) activities and molecular characterization of rhizobacterial strains isolated from soybean (Glycine max L. Merril) plants against charcoal rot pathogen, Macrophomina phaseolina. Biotechnol. Lett. 2011, 33, $2287-2295$. [CrossRef] [PubMed]

63. Jain, S.; Choudhary, D.K. Induced defense-related proteins in soybean (Glycine max L. Merrill) plants by Carnobacterium sp SJ-5 upon challenge inoculation of Fusarium oxysporum. Planta 2014, 239, 1027-1040. [CrossRef] [PubMed] 